Кизилова В. В., доктор філол. наук, професор, професор кафедри філологічних дисциплін ДЗ «Луганський національний університет ім. Тараса Шевченка» (м. Старобільськ, Україна)

\title{
ТЕМА ПРИРОДИ У ТВОРАХ ЄВГЕНА ГУЦАЛА ДЛЯ І ПРО ДІТЕЙ
}

У статті проаналізовано твори Євгена Гуцала для $і$ про дітей в аспекті спещифіки розкриття в них природознавчої тематики. Зроблено акиент на залежності форм зображення природи від вікового цензу читача. Наголошено на майстерності автора синхронізувати об'єктивну інформащію щзодо навколишньої дійсності з індивідуальною емочійною зарядженістю оповідача. Споглядальна манера письма, синтез реалістичної точності і словесно-художньої образності, апелячія до маркерів украӥнської культури, вміння вести діалог із читачем невимушено, просто, тонко відчуваючи найменші порухи душі, вирізняють прозу Свгена Гуцала для і про дітей.

Ключові слова: література для дітей $і$ про дітей, автор, читач, персонаж, проза, природа, тема.

В статье проанализированы произведения Евгения Гуиало для детей и о детях в аспекте своеобразия раскрытия темы природы. Акцентировано внимание на зависимости форм изображения природы от возрастного иенза читателя, умение автора синхронизировать объективную информацию об окружающем мире с индивидуальной эмочиональной нагрузкой рассказчика. Созерцательная манера письма, синтез реалистической точности и словесно-художественной образности, апелляция к маркерам украинской культуры, умение вести диалог с читателем непринужденно, просто, тонко ощущая малейшие движения души, характеризуют прозу Евгения Гуцало для детей и о детях.

Ключевые слова: литература для детей, литература о детях, автор, читатель, персонаж, проза, природа, тема.

The works of YevhenHutsalo for and about children are analyzed in the article in the aspect of peculiarity of descovering the theme of nature. The attention is accentuated to the dependence of forms of nature representation from the age qualification of the reader, author's ability to synchronize objective information about environment with individual emotional loading of the narrator. Contemplative manner of writing, synthesis of realistic precision and verbal and artistic figurativeness, appeal to markers of Ukrainian culture, ability to dialogue with the reader without embarrassment, simply, subtly feeling the smallest movements of the soul, characterize the prose of YevhenHutsalo for and about children.

Key words: literature for children, literature about children, author, reader, character, prose nature theme.

Євген Гуцало належить до представників яскравої й суперечливої епохи шістдесятництва, що дала українству духовних i національних велетнів, художні твори яких актуалізували несподівані й невластиві тодішній тоталітарній епосі концепти. Буття як таке, що не прив'язане до соціальнихнорм i кордонів, комуністичних ідеалів, зміщення ціннісних 
орієнтирів у бік духовних життєвих констант, увага до людини й людяності, внутрішнього світу особистості характеризують прозу Євгена Гуцала.

Панорама сучасного «гуцалознавства» - літературознавчі дослідження, статті, есе й рецензї Ю. Барабаша, I. Бойцун, О. Глушка, В. Дончика, М. Жулинського, М. Ільницького, А. Кравченка, Н. Навроцької, М. Наєнка, Л. Новиченка, В. Плюща, В. Романенка, М. Стрельбицького, П. Федченка, М. Хороб, О. Чепурної та ін. Науковці мовлять про індивідуальні риси поетики творчості Євгена Гуцала, його художньо-естетичні принципи, специфіку побудови художнього світу, роль письменника у зрушенні вагомих естетичних процесів, притаманних прозі 60-х років тощо.

Апеляція до світу дитини у творчості письменника невипадкова: дитинство ж бо $є$ першоосновою людського життя, завдяки вродженому інстинкту відчувати добро і зло, щирій наївності, емоційній простодушності й довірливості, умінні бачити звичайні речі як незвичайні руйнуються будь-які ідеологічні табу, відкривається можливість поглянути на нескінченний світ, вивищитися над буденною сірістю, моральною забрудненістю, жорстокістю й несправедливістю. У творах письменника для і про дітей актуалізовано спогади власного дитинства, у них увиразнено власний духовно-естетичний світ, його бачення і сприйняття автором, що «має більш естетичний характер, ніж сприйняття дорослого <..> Перевага у дитячому сприйнятті речей над простором робить світ незрівнянно більш міцуно розчленованим, ніж $у$ сприйнятті дорослого» [Флоренский 1990:88].

Євген Гуцало не лише відтворює факти свого зі свого дитинства, iз глибин дитячих спогадів він дістає на поверхню ті почуття й емоції, що доводилося переживати, привідкриває незвідану душу людини, iї підсвідомі імпульси, й почуття. «Пам'ять наша - глибокий чарівний колодязь, <..> з його немислимо далекого дна, так само проглядається моє дитинство, й ми дивимося одне одному в очі, мовчимо, ніби в своєму мовчанні теж хочемо зрозуміти якусь загадку, проникнути в таємницю...», - мовить письменник в одному із своїх оповідань [Гуцало 2007:23-24]. У своїх творах для юного 
читача йому вдалося піднятися до чистоти й наївності дитячого світобачення яке, за слушним зауваженням Г. Клочека, є вирішальною у створенні тонкої художньої енергії й одним із основних секретів успішності дитячої літератури [Клочек 2017].

У малій прозі для і про дітей надзвичайно багато спостережень над красою природи, іiі багатством, що оптимізує діалог із читачем, робить твір не лише емоційно привабливим, а й пізнавально-інформативним. Описи природи при цьому залежно від вікового цензу читача будуть змінювати свої форми: найменші діти адекватно реагують на короткі лаконічні описи, де автором схоплено те найважливіше, що підпорядковане «просуванню» сюжету вперед; старші здатні спостерігати красу природи, їі мінливі настрої, що часто пов’язані 3 переживаннями персонажа, перебігом його думок і почуттів.

Свген Гуцало, апелюючи до світу природи, репрезентує іï щоразу поновому, уникаючи штампів й надаючи певного морального й духовного осяяння так, що кожен авторський малюнок приносить юному читачеві естетичну насолоду. У цій розвідці спробуємо окреслити варіанти трансляції теми природи у творчості письменника.

Євген Гуцало часто вдається до синхронного зображення персонажадитини із природою, за допомогою чого авторові вдається розкрити його індивідуальну неповторність: «... бачив сірі бавовняні хмари, бо Женя, задерии й собі голову, угледів їхні волохаті, повні боки. Пливло надвечір'я, студеніло» [Гуцало 2007:69]. Головний герой оповідання «Олень Август», Женя, наділений здатністю мріяти, фантазувати. Він створює у своїй уяві неймовірний таємничий світ з дикими оленями. Попри розчарування, спричинені поведінкою режисера Альтова (він просто хотів похизуватися перед малим і миттю захопив того своїми ідеями щодо зйомки фільму й участі в ньому хлопчика), Женя продовжує жити у вигаданому загадковому світі, де творча особистість комфортно відчуває себе, отримує насолоду від спілкування 3 природою: « $A$ Женя вірив. Він уже уявляв безкраю, зеленоверху тайгу. Хвоя розлилась, як 
море, а він із старими бородачами стоїть на сонці. Вони розгублені, знесилені, не знають, куди йти. Але він рятує їх...» [Гуцало 2007:70-71].

Матеріал природи використовується письменником 3 метою створення певної духовної атмосфери твору, він налаштовує читача на сприйняття тієї емоції, що в той чи той момент переживає герой: «A небо чисте, по-молодому усміхнене. Воно синіє так, наче там висіяно море волошок, і фіалок, і півників, $i$ щуе всячину квітів, щуо не в’януть, хоч би яка спека, щзо не схиляють головок у жалобі, хоч би яке сонцее смажило» [Гуцало 2007:13]. Споглядаючи красу навколишнього світу, письменник вдається до використання зорових, тактильних, нюхових асоціативних компонентів: слово осінь - туге й жовте, наче віск, слово пролісок - бліде й од нього пахне сніжком, слово зозуля ніжно-зелене: такимбув пух на вербах, коли та почала співати в цьому році; у тополиної тіні запах студений і наче гіркий, а від акацієвої тіні начебто віє задушливими дурманними солодощами тощо [Гуцало 2007:14-15]. У наведених прикладах спостерігаємо не стільки об’єктивну інформацію щодо навколишньої дійсності, скільки індивідуальну емоційну зарядженість оповідача, його настрій, спроможність до неспішного усвідомлення краси природи, здатність відчути себе іï частиною.

Чимало у творах Євгена Гуцала графічних малюнків, що відтворюють цілком реальний пейзаж: «Посеред села - річка, берега якоӥ густо поросли очеретом. Луги стеляться широкі, по лугах де-не-де стоять стіжки сіна. Луги великі, по них, окрім річки, світяться більші й менші озера, навколо яких ростуть верби та берези. А саме село розляглось на узвишшях, довкола річки, озер та лугів. Навесні тут розливається вода, зеленіють, розвиваючись, дерева, прилітає птаство, зацвітають квіти в лугах, зацвітають садки...» [Гуцало 2007:87]. Наведений приклад завдяки достеменній передачі обрисів, краєвидів, форм має виразні ознаки інтерференції мистецтв (живопису й літератури). Це так званий панорамний малюнок-пейзаж, живописнозображувальні компоненти якого, деталізація, відповідність словесного опису конкретній місцевості передають стани мальовничої української природи. Їх 
засобами у творах реалізується пізнавально-інформативна функція: дитина не лише збагачується естетично й емоційно, а й отримує важливу інформацію про навколишній світ.

Євген Гуцало часто концентрує увагу на місцезнаходженні об’єктів по відношенню один до одного: «Трохи пройти сільською околищею, проминути зарослу листатою ожиною балочку - й починається рівний луг, щзо тягнеться до ставу. Від городів зеленіють верби...» [Гуцало 2007:18], - що дає можливість читачеві представити чіткий візуальний образ, образ-картинку. Письменник як тонкий і вдумливий спостерігач не опускає деталей, він фіксує ïx i неквапливо веде розповідь про побачене навкруги. Автор зважає в цьому випадку й на психофізіологію маленького читача (нестійка увага, невміння споглядати, конкретність бачення), тому багатство й красу світу природи він намагається продемонструвати короткими лаконічними замальовками.

Особливий інтерес у творах для і про дітейвикликають спостереження над змінами у природі за порами року. Свген Гуцало, описуючи природня явища, синтезує реалістичну точність і словесно-художню образність: «Відчуваєш, як в обличчя тобі дихає зима. Іній - то лише ї̈ периий вісник, перший посланецьь, якого ти бачищ, самої зими щуе нема... Нема, тільки вловлюєш, як вона морозно дихає в обличчя, $і$ кров твоя швидко пульсує по жилах, так швидко, наче сама радість заструмувала, задзвеніла» [Гуцало 2007:87]. У наведеному фрагменті письменнику за допомогою влучної деталі (з'ява інею) і метафори зима морозно дихає в обличчя вдалося не лише намалювати образ-картинку, а й передати емоції, що охоплюють героя під час ранкових спостережень над змінами, що відбуваються довкола.

Євген Гуцало, мовлячи про красу природи тієї чи тієї пори року, апелює до маркерів української культури, залучає до тексту народні повір’я, прикмети: «I все прислухались, чи попід хатою не ходить мороз. I чи метелищі не чути. Бо коли мороз, бо коли метелицяя (на Стрітення. - В. К.), то зима не відступить перед літом, бо літо забариться, а зима щзе довго володарюватиме» [Гуцало 2007:131]. Українські моделі природияк сформовані у свідомості 
реципієнта усталені фрагменти навколишнього світу [Петрухіна 2000:7-8], використані письменником у творах для і про дітей, увиразнюють авторський художній світ, роблять його більш гармонійним, цілісним, підкреслюють архетипність художнього мислення:«Ясною зеленою повіддю розіллялось жито, й здається, наче увесь світ затопило воно, й по всій неозорій землі котяться хвилі, а зверзу по них вигойдується та хлюпочеться сонячне проміння»; "Спів жайворонків такий ясний, такий прозорий, що здається, наче й не пташки позависали в просторі поміж небом і землею, що сам вільний польовий простір співав, щзо звучать дивовижні разки сонячного намиста, натягнуті від стебел молодого жита до небесних високостей» [Гуцало 2007:15, 22]. Автор невипадково звертається у своїх текстах до поширених у фольклорі образів калини, верби, степу, жита, жайворонка й ін., - що узгоджуються як 3 національним, так і 3 авторським контекстом, працюють на розкриття «ментальної орієнтованості світобачення» (Л. Петрухіна), емоційного і психологічного стану героя.

Тему змін пір року. Свген Гуцало майстерно обігрує в оповіданні «Одуд» на прикладі стосунків хлопчика Андрійка й лісового птаха, якого пораненим знайшов батько в лісі і приніс додому. Через пошкоджене крило одуд змушений був лишитися зимувати в Андрійка: чекав його зі школи, вчив уроки й увесь час разом із хлопцем спостерігав за змінами, що відбуваються в природі.

Юному читачеві імпонує опис птаха, що нічим не нагадує підручник із зоології: енциклопедичні відомості в тексті подаються очима Андрійка, який прагне поділитися своїми спостереженнями: «Його (Андрійка - В. К.) вражав $i$ тоненький та довгий ніс, і мала голівка, на якій стовбурчився чубчик, де кожна пір'їнка в оранжево-чорну смужку. I як же славно вмів одуд носити свій чубок! Коли, видно, був у доброму настрої, то гарно складав барвистий чубок, пір'їнка в пір'їнку. А коли, траплялося, гнівався, то розпускав його так, як індик хвоста» [Гуцало 2007:121]. 
Автор акцентує увагу на взаємодії дитини i пташки, показує взаємопроникненість світу людини i світу природи.Зображуючи персонажівіз фауни, письменник виступає не лише оригінальним спостережливим натуралістом, а насамперед майстром слова, засобами якого вдалося сказати дитині-читачу найважливіше: любіть життя й усе живе довкола: «Обережно клав пташку собі до грудей, і так обом добре було, добре! Одуд ховав довгого дзьобика Андрійкові під пахву, $i$, завмерши, вони слухали одне одного: одуд слухав хлопчину, а той слухав пташку» [Гуцало 2007:121]. Відчуття захищеності, родинного тепла й затишку передані автором на прикладі стосунків Андрійка й одуда. Доглядаючи поранену пташку, хлопчик навчився бачити красу навкруги, бути спостережливим, уважним і небайдужим.

Лірична тональність твору, стильова манера письменника 3 його тяжінням до імпресіоністичної традиції дала можливість донести до читача захоплення красою навколишнього світу і змінами, що відбуваються в природі 3 приходом зими, осені, весни. «Як спрагло ждалось весни, як славно в тім роцуі наставала вона! Ще начебто вчора грали білі завірюхи - оркестри зими, а вже сьогодні - немає снігу, наче й не було. А вже завтра сохне земля, парує. А вже позавтра - трава зеленіє, щуе за якийсь час - верба цзвіте, кульбаба, мати-й-мачуха, маргаритки, гусяча цүибулька, анемони дібровні, білі» [Гуцало 2007:125].

Автор значну увагу в оповіданні приділяє описові поведінки птаха, що зумовлена змінами в природі. Читачем вона не стільки розуміється, скільки відчувається завдяки майстерності Євгена Гуцала відтворити форми і стани природи, збагнути їх глибинну суть: «3 того дня, як зазеленіла прибрана ялинка, одуд, здається, став помічати тільки ї. I як заснув під ялинкою в перший вечір коло діда Мороза, щуо тримав за спиною велику торбу з гостинияли, то так $і$ другого вечора спав під тією торбою, й третього» [Гуцало 2007:125].

Як бачимо, матеріал природи у творчості Євгена Гуцала для і про дітей посідає посутнє місце. Як художній факт, він використовується автором 3 
метою створення певної атмосфери твору, розкриття емоційних станів його персонажів, налаштування читача на сприйняття духовно-естетичних проблем. Зважаючи на рецептивні можливості дитячої аудиторії, зумовлені насамперед віковими психофізіологічними особливостями (здатності залежно від віку адекватно реагувати на розлогі/лаконічні описи природи, сприймати змалювання стану природи вкупі 3 перебігом думок і почуттів героїв твору тощо), автор щоразу демонструє простоту й довершеність художнього слова, поетичну образність, пластичність у зображенні об'єктів природи. Споглядальна манера письма Євгена Гуцала, синтез реалістичної точності i словесно-художньої образності, вміння вести діалог із читачем невимушено, просто, тонко відчуваючи найменші порухи душі, апеляція до маркерів української культури дозволяє відчути особливу красу природи, авторський погляд на світ природи й людину в ньому, замилування навколишньою красою. Завдяки невтомним авторським пошукам відкриття світу, твори Свгена Гуцала для і про дітей стали позачасовими, не залишають байдужими сучасних юних читачів.

\section{БІБЛІОГРАФІЯ}

Гуцало 2007 - Гуцало Є. Сім’я дикої качки: для мол. та серед. шк. віку. Упорядкув. та передм. Лесі Вороніної / Гуцало С. - К. : Школа, 2007. - 218 с.

Клочек 2017 - Клочек Г. Світ Краси і Любові, дарований поезією [Електронний ресурс] / Григорій Клочек. - Режим доступу: http://www.chl.kiev. ua/key/Books/ ShowBook/449.

Петрухіна 2000 - Петрухіна Л. Е. Образи природи як стани екзистенції у поезії (теоретичний аспект) : автореф. на здоб. наук. ступеня канд. філол. наук : спец. 10.01.06 «Теорія літератури» / Петрухіна Людмила Едуардівна ; Львівський національний університет імені Івана Франка. - Львів, 2000. - 20 с.

Флоренский 1990 - Флоренский П. А. Сочинения в 2 т. / П. А. Флоренский. - Т. 2 : У водоразделов мысли. - М. : Правда, 1990. - 181 с. 